University of Nebraska - Lincoln

DigitalCommons@University of Nebraska - Lincoln

U.S. Environmental Protection Agency Papers

U.S. Environmental Protection Agency

2006

The fathead minnow in aquatic toxicology: Past, present and

future

Gerald T. Ankley

U.S. Environmental Protection Agency, ankley.gerald@epa.gov

Daniel L. Villeneuve

U.S. Environmental Protection Agency

Follow this and additional works at: https://digitalcommons.unl.edu/usepapapers

Part of the Civil and Environmental Engineering Commons

Ankley, Gerald T. and Villeneuve, Daniel L., "The fathead minnow in aquatic toxicology: Past, present and future" (2006). U.S. Environmental Protection Agency Papers. 94.

https://digitalcommons.unl.edu/usepapapers/94

This Article is brought to you for free and open access by the U.S. Environmental Protection Agency at DigitalCommons@University of Nebraska - Lincoln. It has been accepted for inclusion in U.S. Environmental Protection Agency Papers by an authorized administrator of DigitalCommons@University of Nebraska - Lincoln. 
Review

\title{
The fathead minnow in aquatic toxicology: Past, present and future
}

\author{
Gerald T. Ankley*, Daniel L. Villeneuve \\ US Environmental Protection Agency, Office of Research and Development, National Health and Environmental Effects Research Laboratory, \\ Mid-Continent Ecology Division, 6201 Congdon Boulevard, Duluth, MN 55804, USA
}

Received 9 September 2005; received in revised form 3 January 2006; accepted 16 January 2006

\begin{abstract}
This paper reviews the roles of the fathead minnow (Pimephales promelas) as a small fish model in the field of aquatic toxicology. The species has been (and is) extensively used both for regulatory testing and research, especially in North America. For example, tests with the fathead minnow, ranging from 48-h lethality through partial and full life-cycle assays, are routinely used for regulatory programs aimed at assessing potential risks of new chemicals such as high-production volume materials and pesticides, as well as impacts of complex mixtures like effluents. The species also has been used for a wide variety of research applications focused on topics like the development of quantitative structure-activity relationship models, mixture toxicity, extrapolation of the effects of chemicals across species, and understanding the results of laboratory assays relative to impacts in the field. Attributes of the fathead minnow also make it an excellent model for addressing new challenges in aquatic toxicology, including identification of sensitive life-stages/endpoints for chemicals with differing modes/mechanisms of action, predicting population-level effects based on data collected from lower levels of biological organization, and exploring/understanding the emerging role of genomics in research and regulation.
\end{abstract}

Published by Elsevier B.V.

Keywords: Fish; Toxicity testing; Regulation; Review

\section{Contents}

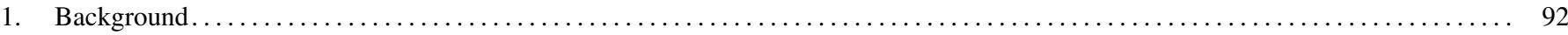

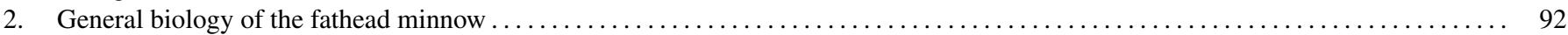

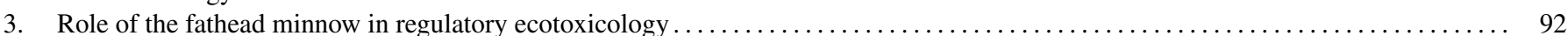

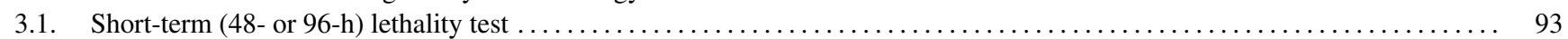

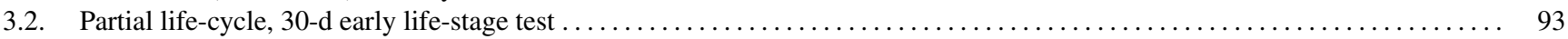

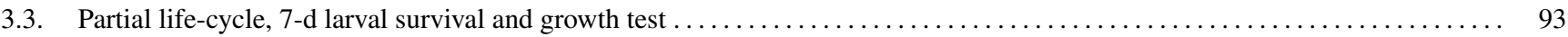

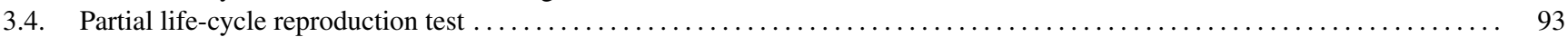

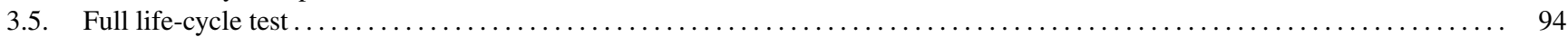

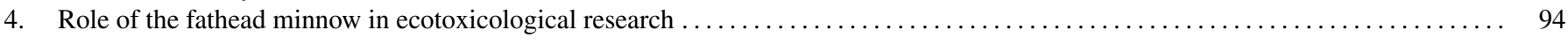

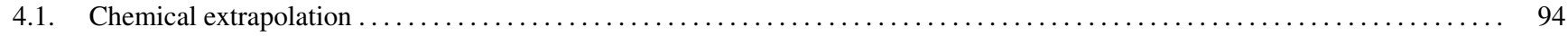

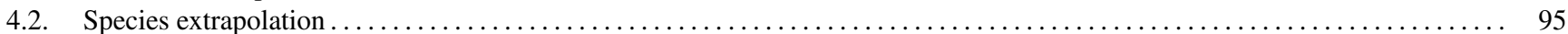

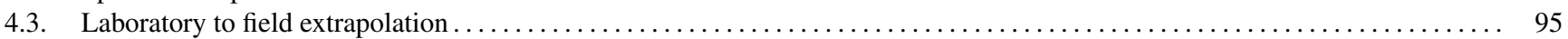

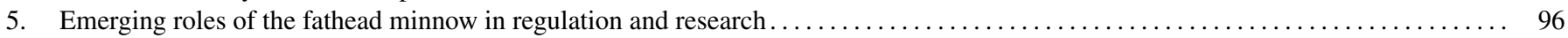

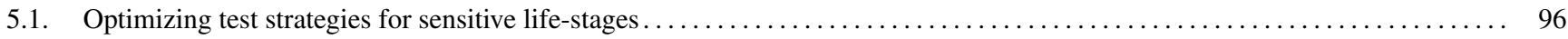

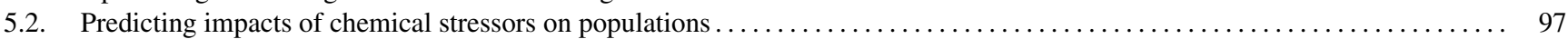

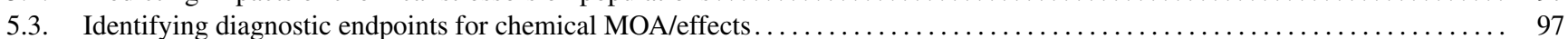

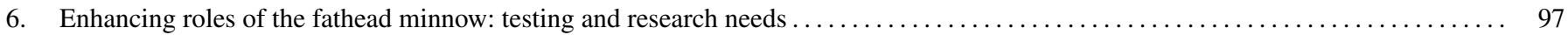

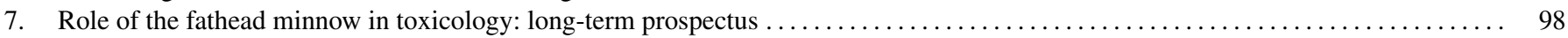

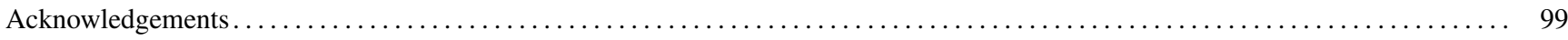

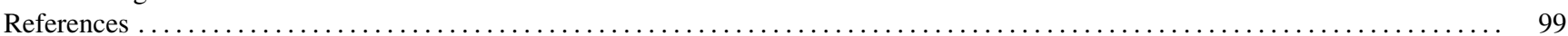

* Corresponding author. Tel.: +1 218529 5147; fax: +1 2185295003.

E-mail address: ankley.gerald@epa.gov (G.T. Ankley). 


\section{Background}

Fish were first utilized in toxicity tests more than 140 years ago (Penny and Adams, 1863, as cited in Hunn, 1989) but, until the 1940 s, were used only sporadically to assess the toxicity of single chemicals or mixtures (Hunn, 1989). The 20 years after World War II saw a marked increase in the use of fish as toxicological models, including the development of "standard" methods for short-term (96h) tests focused on lethality (Doudoroff and Katz, 1950, 1953; APHA, 1960). The most commonly used fish in early testing were juveniles or adults of species with relatively long life cycles such as different salmonids, bluegill (Lepomis macrochirus) and goldfish (Carassius auratus). This was largely due to their availability through hatcheries and/or pet supply outlets (Hunn, 1989). During the 1960-1970s, there was an increasing recognition of the importance of longer-term tests with sub-lethal endpoints to accurately assess potential chronic risks of chemicals to fish (Mount, 1977; Stephan, 1989). To make these longer-term tests logistically reasonable, scientists moved from using older/larger fish to early developmental stages (McKim, 1977), and/or smaller species with comparatively rapid life cycles. Today, small fish commonly used as toxicology research models around the world are largely freshwater species, such as the fathead minnow (Pimephales promelas), Japanese medaka (Oryzias latipes) and zebrafish (Danio rerio; Ankley and Johnson, 2004). Since initial studies with the species in the 1950 s, the fathead minnow has become the most widely used small fish model for regulatory ecotoxicology in North America. The purpose of this short review is to describe how the fathead minnow has been (and is) used in the field of regulatory toxicology, and assess the potential of this species as a model for emerging needs and issues in toxicological research.

\section{General biology of the fathead minnow}

The fathead minnow is a member of the ecologically important Cyprinidae family, with a relatively broad distribution in both lotic and lentic environments across North America (Isaak, 1961; Devine, 1968; Eddy and Underhill, 1974; Held and Peterka, 1974). The species is an opportunistic omnivore, and tolerant of a wide range of basic water quality characteristics including $\mathrm{pH}$, alkalinity/hardness, turbidity, and temperature (McCarraher and Thomas, 1968; Bardach et al., 1966; Brungs, 1971a,b; Mount, 1973). The adult male fathead minnow is larger than the female (3-5 g versus $2-3 \mathrm{~g}$, respectively) and, when reproductively active, males exhibit several secondary sex characteristics (e.g., dark banding, dorsal pad, and nuptial tubercles) not normally seen in females (Flickinger, 1969; Smith, 1974; Smith and Murphy, 1974; USEPA, 1987). Courtship/reproductive behavior in the fathead minnow is elaborate and relatively well-defined (McMillan and Smith, 1974; Ming and Noakes, 1984; Cole and Smith, 1987). Following spawning, males are highly territorial, actively guarding nest sites where the adhesive eggs had been deposited by the females (Andrews and Flickinger, 1973). The embryos proceed through several well-defined developmental stages, which are easily viewed through the transparent egg chorion (USEPA, 1996), and hatch within $4-5 \mathrm{~d}$ (at $25^{\circ} \mathrm{C}$ ). Following hatch, the larvae are active and begin feeding almost immediately (USEPA, 1987). Under optimal conditions the fathead minnow achieves reproductive maturity within 4-5 months of hatch and, depending on water temperature and photoperiod, can spawn continually for several months (Brungs, 1971a).

Given the fathead minnow's tolerance to a wide range of water types, and its relatively well-defined reproductive/developmental cycle, this species has proven amenable to continuous culturing in laboratories throughout the world (USEPA, 1987). Cultures composed of fish of different ages (usually segregated as "groups" on a weekly to monthly basis) are typically held under constant environmental conditions at a temperature of $25^{\circ} \mathrm{C}$ and a photo-period of $16 \mathrm{~h}$ light: $8 \mathrm{~h}$ dark. Pairs, or occasionally small groups, of sexually mature adults are held in tanks with spawning substrates from which eggs can be collected, staged, and hatched (Benoit and Carlson, 1977). Larva need live food through about $30 \mathrm{~d}$ post-hatching, a requirement that has been successfully met through use of commercially available brine shrimp (Artemia) cysts, which can be readily hatched in the laboratory (USEPA, 1987). Older fathead minnows can be maintained using commercially available diets, most commonly frozen adult brine shrimp (USEPA, 1987).

With a few notable exceptions (e.g., Manner and Casimira, 1974; Gale and Bunyak, 1982; Wabuke-Bunoti and Firling, 1983), until recently, much of the basic biology research with the fathead minnow focused on life-history characteristics in a field setting. However, with the advent of use of this species as a test model to detect endocrine-disrupting chemicals (EDCs; Ankley and Johnson, 2004), more has become known about the basic reproductive physiology/development. For example, while many early studies had established the continual (or fractal) nature of fathead minnow spawning (e.g., Radcliff, 1931; Hasler et al., 1946), only relatively recently has this been quantitatively assessed in terms of variations in key parameters (e.g., gonadal staging, sex steroids) in the reproductive endocrine axis of the fish (Harries et al., 2000; Jensen et al., 2001). Similarly, there has been recent detailed work concerning sexual development in the fathead minnow (e.g., Panter et al., 2002; Van Aerle et al., 2002), as well as the identification and characterization of several genes and proteins critical to sexual development and reproduction (e.g., Korte et al., 2000; Halm et al., 2001, 2003; Wilson et al., 2004; Villeneuve et al., 2005).

\section{Role of the fathead minnow in regulatory ecotoxicology}

Before the formation of the US Environmental Protection Agency (EPA), fish testing for regulatory/monitoring purposes resided largely in the Public Health Service, which had aquatic testing facilities in Cincinnati, $\mathrm{OH}$. It was there that fathead minnows started to be used for routine testing. Stocks of the fish were initially collected from holding ponds where they were being grown as food for muskellunge (Esox masquinongy) being reared for stocking (D.I. Mount, Duluth, MN, personal communication). Because of their amenability to handling and controlled experimentation, fathead minnows were used through 
the 1950s in different types of lethality assays, including comparatively long-term $(30 \mathrm{~d})$ tests with flow-through chemical delivery (D.I. Mount, personal communication). In the 1960s, the first full life-cycle tests with fathead minnows (with the pesticides malathion and 2,4-D) were conducted and described in the open literature (Mount and Stephan, 1967). The EPA was formed in 1970, and several testing labs were assigned to support the new Agency, including a relatively new facility in Duluth, MN. Since then the Duluth EPA laboratory has conducted much of the methods development/research with the fathead minnow needed to support regulatory activities.

Fathead minnows have been used for a number of tests designed for different regulatory applications. The tests encompass everything from very basic approaches evaluating lethality as an endpoint in 48/96-h assays, through complex partial and full life-cycle tests involving a battery of both apical (whole animal) and mechanistic/diagnostic endpoints. The variety of test methods employed have been developed and refined over time in direct response to evolving paradigms in aquatic ecotoxicology and the changing regulatory needs of the Agency. Different fathead minnow test designs and some of their major regulatory applications are discussed below.

\subsection{Short-term (48- or 96-h) lethality test}

The most basic fathead minnow test design is a standard 48- or 96-h lethality assay initiated with juvenile (ca. $30 \mathrm{~d}$ post-hatch) animals (USEPA, 1989; OECD, 1992a; ASTM, 2000a). From a regulatory perspective, the 96-h lethality assay is one in a suite of several tests for programs ranging from pesticide registration to derivation of Water Quality Criteria (WQC). The 96-h test also is frequently used to "screen" the toxicity of new and existing (non-pesticidal) materials, such as high-production volume chemicals, listed on the EPA TSCA (Toxic Substances Control Act) inventory (Smrchek et al., 1993; Zeeman, 1995). The TSCA program has only limited authority to require testing (Zeeman, 1995), so the short-term, and comparatively inexpensive, nature of the lethality assay renders it amenable to the generation of at least some chemical-specific ecotoxicity data when deemed necessary. The short-term lethality assay also is routinely used as a "range-finding" test in helping dictate the need for, and/or setting appropriate test concentrations for longer-term fathead minnow assays such as those described below.

\subsection{Partial life-cycle, 30-d early life-stage test}

Fathead minnows have been (and are), commonly utilized in longer-term, partial life-cycle tests to determine lethal and sublethal effects both of single chemicals and complex mixtures. Early life-stage tests, in particular, have received much use, as there is evidence that data from assays conducted during early development can be predictive of chemical effects in full lifecycle tests (McKim, 1977). Early life-stage tests are typically initiated with <24-h-old fathead minnow embryos, and conducted through $30 \mathrm{~d}$ post-hatch (USEPA, 1989; OECD, 1992b; ASTM, 2000b). In addition to effects on survival (including hatching success) and growth (wet weight and, occasionally, standard length), gross morphological alterations in the juveniles can be assessed at completion of the assay. The EPA pesticides program frequently uses data from the fathead minnow 30-d early life-stage test as part of the registration process (USEPA, 1989). Depending on results of the 30-d test, a more extensive full life-cycle exposure may be conducted (described below). Results from the fathead minnow 30-d early life-stage test also are commonly used in the derivation of national WQC by EPA, as indicative of the chronic toxicity of chemicals to fish when full life-cycle toxicity data are not available (Stephan et al., 1985).

\subsection{Partial life-cycle, 7-d larval survival and growth test}

An abbreviated version of the 30-d early life-stage fathead minnow test is used extensively by another EPA regulatory program. Norberg and Mount (1985) first described a 7-d test initiated with $<24$-h old fathead minnow embryos, with the primary endpoints of survival and growth (dry weight at test conclusion). Slight variations of the test have been proposed and evaluated (e.g., Pickering, 1988; Pickering and Lazorchak, 1995). The assay has been standardized (USEPA, 1994), and is currently used by EPA as a key component of the whole-effluent monitoring program, administered under the authority of the National Pollution Discharge Elimination System (NPDES). At present, periodic tests with the fathead minnow are required by more than 5000 NPDES biological monitoring permits nationwide in the US (T. Norberg-King, USEPA, Duluth, MN, personal communication). Use of the fathead minnow (or any other biological) test in this fashion is distinct from new chemical testing (e.g., TSCA chemicals, pesticides) in a two regards. First, virtually all the testing involves complex mixtures, as opposed to single chemicals. Second, unacceptable toxicity "excursions" can result in regulatory actions, including mandatory toxicity identification/reduction evaluations and/or treatment alterations that occur after, rather than before, toxic chemicals have been released to the environment (USEPA, 1991).

\subsection{Partial life-cycle reproduction test}

Another partial life-cycle test with the fathead minnow that could achieve wide-spread regulatory usage involves mature adults. In the mid 1990s, EPA initiated the development of a screening and testing program for substances (EDCs) which could adversely affect reproduction and development through interactions with the hypothalamic-pituitary-gonadal (HPG) axis (USEPA, 1998). A number of tests were recommended and have been developed for this program, including a shortterm $(21 \mathrm{~d})$ reproduction assay initiated with actively spawning adults. Endpoints for the test include a number of traditional apical indicators of reproductive viability (fecundity, fertility, hatch), as well as "biomarkers" diagnostic of chemical interactions with specific aspects of the HPG axis, such as plasma concentrations of sex steroids and the egg yolk protein vitellogenin, gonadal histopathology, and alterations in secondary sexual characteristics (Harries et al., 2000; Ankley et al., 2001). This particular assay/application has unique characteristics from two perspectives. First, biomarkers have seldom been used 
for regulatory purposes, in part because of difficulties in linking molecular/biochemical/cellular changes to apical outcomes (Hutchinson et al., 2006). A second unique aspect of the assay, which has regulatory implications broader than EDC testing, involves implicit consideration of reproduction as an endpoint. Other than full life-cycle tests, reproductive viability data are not collected from the fish assays typically used for regulatory purposes. Nonetheless, reproduction can be a sensitive "effects window" for certain toxicants (Ankley and Johnson, 2004), and reproductive output provides data critical to predicting possible population-level impacts of chemicals. As such, a short-term reproduction assay should prove to be of utility to regulatory programs other than those focused on EDCs (e.g., pesticide registration), as well as field monitoring (Parrott, 2005).

\subsection{Full life-cycle test}

The most extensive test design with fathead minnows used for regulatory purposes is the full life-cycle assay (USEPA, 1982). This test is initiated with $<24$-h-old embryos and continues through maturation of the fish and subsequent production of the F1 generation, which typically are reared through $30 \mathrm{~d}$ of age. The assay is relatively resource- and time-intensive, lasting on the order of 5-6 months. As a result, the test is not used very frequently either for regulatory or research purposes. One EPA regulatory authority that utilizes the fathead minnow full life-cycle test, at least occasionally, is the pesticide registration program. It is estimated that about 40-50 fathead minnow full life-cycle tests have been conducted in conjunction with the program (Les Touart, EPA, Washington, DC, personal communication). There are also examples of fathead minnow full life-cycle tests with high-visibility chemicals considered to be of potential ecological risk (albeit for which there may not currently be formal framework for regulation) available in the open literature. One recent study of this type was with the EDC $17 \alpha-$ ethinylestradiol (EE2) published by Länge et al. (2001).

\section{Role of the fathead minnow in ecotoxicological research}

Because toxicology is a relatively applied science, clear separation of research from regulation is difficult. For the purpose of this review, we have differentiated the two types of testing based on whether the resultant data directly impact decision making (regulation) versus whether the data address broader conceptual issues (research). Because of the fathead minnow's regulatory importance, tolerance both of handling and different water quality characteristics, and the existence of a large amount of species-specific biology and toxicity data, the fish has been extensively used to explore different aspects of exposure to, and effects of, contaminants in both laboratory and field settings. Description of all the types of contaminant-oriented research for which the fathead minnow has been used is not practical. However, below are several examples of research with the species focused on three broad areas of extrapolation uncertainty in ecological risk assessments for chemicals: (1) across chemical structures (singly or mixtures), (2) among species, and
(3) from laboratory to field. These examples do not comprehensively describe hypotheses, results, and conclusions associated with a particular study or set of studies but, rather, are intended as an illustration of the broad range of toxicological research for which the fathead minnow has been used as a test model.

\subsection{Chemical extrapolation}

A significant challenge for ecological risk assessments is prediction of potential biological effects of the tens of thousands of new and existing chemicals (and metabolites) for which no data or avenues (e.g., resources) to generate new data exist. Quantitative structure-activity relationship (QSAR) models offer a viable approach to predict the toxicity of chemicals based on structural characteristics of compounds. Literally hundreds of different QSAR models for biological responses have been developed over the past half century, however, most are based on relatively small data sets of variable quality. In recognition of this, in the early 1980s a large-scale testing program was initiated with the fathead minnow to develop a knowledge-base comprised of toxicity (lethality) data for a large group of structurally diverse chemicals (Veith et al., 1988). For these studies, the 96-h fathead minnow test was conducted with more than 600 different organic chemicals, including many from the EPA TSCA inventory (Russom et al., 1997; Bradbury et al., 2003). The effort was unique both in terms of scope (i.e., number/variety of chemicals tested, evaluation of a biologically relevant in vivo response) and the quality of the data generated (all tests were flow-through exposures with measured chemical concentrations). Exposure/effects data from the fathead minnow 96-h tests were subsequently used to develop QSAR models to predict lethality based on probable mode/mechanism of action (MOA) of unknown chemicals (Russom et al., 1997; Bradbury et al., 2003). These QSAR models have been extensively used both for regulatory and research purposes (Zeeman, 1995; Bradbury et al., 2003, 2004). Work is ongoing to develop QSAR models using data of a similar quality from longer-term, sub-lethal assays with the fathead minnow, specifically the 30-d early lifestage test (Call and Geiger, 1992; C. Russom, USEPA, Duluth, $\mathrm{MN}$, personal communication).

Most current environmental regulations do not explicitly consider the combined effects of chemical mixtures, and this is widely recognized as a significant shortcoming in ecological risk assessments. Both the 96-h fathead minnow lethality and 30-d early life-stage tests have been used as the basis for generating data for comparing different approaches to predict the toxicity of mixtures of chemicals (Broderius and Kahl, 1985; Broderius et al., 1995, 2005). These tests are defined/standardized well enough that, in conjunction with careful dosimetry (i.e., flowthrough experiments with measured toxicant concentrations), the relatively precise data needed for assessing chemical interactions can be obtained. For example, Broderius and colleagues were able to show that mixtures of chemicals with a common (narcosis) MOA exhibited additive toxicity consistent with concentration addition, while mixtures of chemicals with dissimilar MOA caused toxicity that was less than additive. More recent studies by Brian et al. (2005) with the fathead minnow also 
demonstrated additive effects for chemicals (estrogen receptor agonists) with a similar MOA. The results of these various mixture studies are not unexpected in terms of toxicological principles, however, the generation of in vivo data of quality sufficient to rigorously test mixture concepts using any species/test design (including standard mammalian models such as rats) has rarely been successfully achieved. As such, the mixture toxicity data from the fathead minnow studies serve as an important technical underpinning for the models that increasingly are being applied to dealing with mixtures in ecological assessments.

\subsection{Species extrapolation}

The question as to how well chemical toxicity results obtained with one species can be extrapolated to another is central to both human health and ecological risk assessments. In ecological risk assessments this is a particularly challenging task because toxicity tests with a few (sometimes one) species need to be predictive of possible effects in thousands of untested species. There are different experimental approaches to evaluate the success/reliability of species extrapolation assumptions. Some focus on quantitative differences among species (e.g., attempting to identify whether a particular organism/test design is sensitive relative to other species), while other approaches strive to assess qualitative differences/similarities among species with regard to toxicity pathways. The fathead minnow has been utilized for both approaches. For example, there have been a number of analyses over the past 20 years comparing the sensitivity of the fathead minnow to other fish and invertebrate species (e.g., Doherty, 1983; Thurston et al., 1985; Suter and Rosen, 1988). The outcome of these types of analyses has been fairly consistent, in that no species is always the most sensitive to the test chemicals, and closely related organisms usually exhibit more similar sensitivities than phylogenetically distant species. These observations are also consistent with the results of a relatively recent project completed by scientists associated with the US Geological Survey, which focused on whether different toxicity test designs with commonly used aquatic species, including the fathead minnow, would be protective of threatened and endangered North American fish species (Sappington et al., 2001; Besser et al., 2005; Dwyer et al., 2005a,b). Experimental designs that they considered with the fathead minnow included 96-h lethality assays and the 7- and 30-d early life stage tests. No one species was most sensitive to all the chemicals or chemical mixtures. However, in general, results obtained using the fathead minnow (and other surrogate species such as the salmonid Oncorhynchus mykiss) were predictive of the toxicity of chemicals to a variety of threatened or endangered fishes, indicating that the basis for extrapolation of chemical effects among the species was valid.

An additional, complementary approach to considering the scientific credibility of across-species extrapolations is the comparative evaluation of toxicity pathways. A toxicity pathway can be defined as the "initiating" interaction of a chemical with a biomolecule(s), followed by the cascade of responses at multiple levels of biological organization, which ultimately result in adverse outcome(s) in the whole animal (Bradbury et al., 2004;
Miracle and Ankley, 2005). A simple example of this type of approach was provided by Cook et al. (1993), who utilized the presence/absence of the $\mathrm{Ah}$ receptor as a basis for identifying aquatic animals/life-stages at greatest risk for toxicity of 2,3,7-8 tetrachlorodibenzo- $p$-dioxin and structurally related chemicals. More recently, the scientific and regulatory emphasis on EDCs with specific toxic MOA has resulted in the generation of data for comparative assessments of toxicity pathways across species. For example, studies with estrogenic EDCs in several small fish models (fathead minnow, medaka, zebrafish) indicate that, while responses in the whole animal can vary among species, common molecular initiating events (e.g., binding to and activation of the estrogen receptor) provide a basis for understanding (and predicting) these responses (for review, see Ankley and Johnson, 2004). This type of comparison needs not be limited to consideration of toxicity extrapolations across fish species. For example, studies evaluating the binding of chemicals to fathead minnow and mammalian androgen receptors have helped provide an understanding of the degree of conservation of basic aspects of the HPG axis across vertebrates (Wilson et al., 2004), and aided in the prediction of in vivo responses of fish to androgen receptor agonists and antagonists (Ankley et al., 2003, 2004).

\subsection{Laboratory to field extrapolation}

Ecotoxicologists rely almost exclusively on laboratory data to predict the possible effects of chemicals on organisms in the field. There are a number of challenges to making this extrapolation, and/or determining the degree to which it is valid. The fathead minnow has frequently been used to help assess and improve linkages between the laboratory and field. For example, Mount and coworkers conducted a series of intensive studies in eight different freshwater systems to determine whether two tests designed for whole effluent monitoring, the fathead minnow 7-d survival and growth assay and a 7-d reproduction test with Ceriodaphnia dubia, were predictive of alterations in natural biological communities in the systems (for review, see USEPA, 1991). Overall, results of toxicity tests with water samples collected from the sites were consistent with impacts/lack of impacts in the field $90 \%$ of the time. As such, these studies provided strong indirect support for the concept of using the results of laboratory toxicity tests as a basis for identifying unacceptable water quality from a regulatory perspective (USEPA, 1991).

Because fathead minnows can be successfully used in "caged fish" studies as well as collected from indigenous populations (at least in North America), they are a useful model for making more direct links between the laboratory and field work. A recent example of this involves exposure to/effects of the synthetic estrogen EE2. Ethinylestradiol is a common contaminant of municipal effluents in the low ng/L range (Desbrow et al., 1998; Ternes et al., 1999). Laboratory studies suggest that the fathead minnow is relatively sensitive to EE2, as well as other steroidal estrogens that can occur in effluents. For example, Länge et al. (2001) reported an EE2 lowest-observable effect concentration of $\geq 1 \mathrm{ng} / \mathrm{L}$ in a fathead minnow full life-cycle test. They also reported that EE2 induced production of the estrogen-responsive 
protein vitellogenin (egg yolk precursor) at $\mathrm{ng} / \mathrm{L}$ concentrations, an observation consistent with shorter-term exposures of male fathead minnows to other potent steroidal estrogens (Panter et al., 1998; Lattier et al., 2002). Based on laboratory studies, therefore, there is an indication that vitellogenin can be a sensitive, biologically relevant indicator of exposure of fathead minnows to estrogens in field settings. Hemming et al. (2001, 2004) assessed vitellogenin production in caged fathead minnows held at different points in an effluent discharge to evaluate the distribution and dissipation of estrogenic chemicals, including EE2, associated with a municipal effluent. Vitellogenin production in the caged fish indicated strong temporal and seasonal variations in estrogenicity of the effluent, possibly associated with microbial metabolism of estrogenic chemicals. In a very large-scale field study, Palace, Kidd and coworkers treated an entire lake with EE2, and monitored the status of populations of several aquatic species over the course of months to years. As in laboratory studies, they found that EE2 concentrations on the order of a couple ng/L induced vitellogenin production in natural populations of fathead minnows, as well as inhibiting their reproductive success, leading to virtual extirpation of the species in the lake (Palace et al., 2002a,b). The breadth of research with EE2 and fathead minnows, ranging from partial and full life-cycle tests in the laboratory to caged fish and population studies in the field is uncommon, but illustrative of what can be done in terms of establishing laboratory-field linkages.

A major uncertainty in ecological risk assessments involves accurate prediction of chemical bioavailability. Questions in this area arise both in terms of extrapolation among chemicals, and translation of data obtained in the laboratory under one set of (usually highly controlled) conditions to field settings where physico-chemical variations can greatly confound prediction of bioavailability. The fathead minnow has been used in various capacities to address uncertainties concerning the bioavailability and/or accumulation of organic and inorganic chemicals. For example, early studies by Veith and coworkers, largely with the fathead minnow, were pivotal in defining the relationship between bioconcentration of organic chemicals and their octanol-water partition coefficient (Veith et al., 1979; Veith and Kosian, 1983). This relationship has since served as a conceptual basis for virtually all predictive modeling of the accumulation of organic chemicals from water by fish both in laboratory and field settings (for review, see Gobas and Morrison, 2000). The fathead minnow also has been an important test species for predicting the bioavailability of inorganic chemicals across different laboratory and field settings. For example, the fathead minnow was one of the primary test species that Erickson (1985) relied on to provide data to mathematically define the effects of water quality (primarily $\mathrm{pH}$ ) on the bioavailability/toxicity of ammonia, an analysis which serves as the basis of a national WQC for aquatic life for ammonia (USEPA, 1999). The fathead minnow also has been used as a test model to better understand the aqueous bioavailability of cationic metals to fish and invertebrates. The studies of Erickson et al. (1996) with this species provided definitive data concerning the influence of water quality parameters such as $\mathrm{pH}$, hardness, alkalinity, and dissolved or particulate organic carbon on the toxicity of copper, ultimately contributing to the development of the biotic ligand model as a theoretical basis for defining the bioavailability/toxicity of cationic metals to aquatic species (for review, see Paquin et al., 2002).

\section{Emerging roles of the fathead minnow in regulation and research}

Ecotoxicology remains a relatively rapidly evolving field as new questions and issues arise and as science and technology develops. Over the latter half of the 20th century, the fathead minnow has proven to be a very useful model for addressing needs in both research and regulation. However, at the beginning of the 21 st century, many challenges remain. Below we discuss several efforts underway to address some of the current and pressing challenges in ecotoxicology.

\subsection{Optimizing test strategies for sensitive life-stages}

As discussed briefly above, most current regulatory testing with fish focuses almost solely on aspects of early development, with relatively little emphasis on endpoints related to reproductive output. This has been, in large part, because of the expense of the full life-cycle tests that historically have been used to generate reproductive data. Yet, early development and active reproduction are both sensitive biological "windows" in terms of expression of the toxicity of chemicals. Furthermore, impacts during development and reproduction are the ultimate determinants of population viability and status. Hence, there is a need for cost-effective tests capable of encompassing both life stages. In the fathead minnow, a logical option to achieve this would be linkage of short-term $(21 \mathrm{~d})$ reproduction assays (Harries et al., 2000; Ankley et al., 2001; USEPA, 2002) to the standard 30-d early life-stage test commonly used for this species (USEPA, 1989; OECD, 1992b; ASTM, 2000b). A recent example of this was provided by Ankley et al. (2005), who evaluated the toxicity of a fluorinated surfactant with the 21-d reproduction assay, followed by a 24-d developmental test initiated with embryos from exposed adults. In that experiment, the embryos/larvae were reared under the same treatment regime (water concentrations) to which the adults had been exposed. Results of that study suggested that adult reproduction was more sensitive than early development to the effects of the surfactant. Depending upon the research/regulatory question at hand, variations on the design used by Ankley et al. (2005) are possible, such as rearing embryos from exposed adults in clean water, in addition to chemically treated water. This would enable, for example, direct consideration of the effect of maternally derived chemical on early survival and development. In any case, linkage of the fathead minnow reproduction and early life-stage tests in this fashion would enable, in about a 2-month time period, generation of virtually all the same types of data derived from the much longer full life-cycle test. If this design were used for regulatory purposes, it would be desirable to develop a database concerning sensitivity of the assay relative to full life-cycle tests with a set of chemicals with differing toxic MOA, as well as bioconcentration potential. 


\subsection{Predicting impacts of chemical stressors on populations}

Other than for threatened/endangered species, the goal of most ecological risk assessments is to protect populations and communities of organisms. However, for chemicals this is done based almost solely on laboratory responses of individuals. Population models are increasingly serving as the basis for "translation" of toxicity data from the laboratory into probabilistic predictions of risk to populations (http://www.epa.gov/oppefed1/ecorisk/aquareport.pdf). As for any type of model, population models span a gamut from the very simple (little data needed, but generally weak predictive value) to very complex (good predictive value at the cost of extensive data requirements). There have been several recent examples of the use of data generated from fathead minnow full and partial life-cycle tests with EDCs in population models (Gleason and Nacci, 2001; Grist et al., 2003; Brown et al., 2003; Miller and Ankley, 2004). For example, Miller and Ankley (2004) sought to provide a simple modeling construct that could account for density-dependent logistic population growth (as described by May, 1974) in screening-level assessments, yet be flexible enough to utilize additional information for more complex situations/questions. The model at its most basic level utilizes an annual time step and requires a relatively small amount of information: a life table for the organism of interest, a carrying capacity for the population, and an estimation of the impact of the stressor on key vital rates (e.g., effects on fecundity from partial or full life-cycle reproduction tests). The model described by Brown et al. (2003) has essentially the same goal as that of Miller and Ankley (2004) in utilizing life history characteristics and effects data from laboratory studies to examine population sustainability and recovery, but employs a different model formulation. The Brown et al. (2003) model was formulated from a delay differential equation approach, implemented using a daily time step, and assumed density dependence to be either described by the Ricker equation (Ricker, 1975) or by a Beverton Holt function (Beverton and Holt, 1957). A small time step, as applied by Brown et al. (2003), is more suitable for evaluating temporal effects of exposure to test chemicals that are occurring over a short time period (in an inner-annual time period), but requires greater resolution of data inputs. As modeling approaches such as these evolve, the ability to utilize population predictions as part of routine ecological risk assessments becomes increasingly feasible for regulatory programs.

\subsection{Identifying diagnostic endpoints for chemical MOAleffects}

Recent developments in science, technology and computing have provided an unprecedented ability to study biomacromolecules in aggregate. Techniques to simultaneously measure changes in the expression of large numbers of genes (transcriptomics), proteins (proteomics), and physiological metabolites (metabolomics) enable diagnostic analyses of an organism's response to contaminant stressors in ways not previously possible. It has been suggested that these "omics" approaches will assist toxicologists in several regards, including: (1) identification of MOA to help define toxicity pathways, (2) provision of a basis for extrapolation of chemical effects across species, (3) development of better techniques for dealing with chemical mixtures, (4) identification of biomarkers of exposure and effects for use laboratory and field (monitoring) studies, and (5) enhancement of an understanding of systems-level responses to chemical exposure. A full discussion of the possible role of genomics in ecotoxicology is beyond the scope of this paper, but there are a number of recent reviews on the topic (e.g., Miracle et al., 2003; Shrader et al., 2003; Viant et al., 2003; Snape et al., 2004).

Due to the amount known about the genomes of the medaka and, especially the zebrafish, both these model species have received more attention to date than the fathead minnow relative to genomic research. However, because of the historical use of the fathead minnow for regulation and research, a number of groups are developing the knowledge-base needed to conduct advanced genomics work with the fathead minnow. For example, the Joint Genome Institute of the US Department of Energy has, in conjunction with EPA, developed cDNA libraries for the fathead minnow which include more than 250,000 expressed sequence tags (likely representing on the order of 10,000-12,000 genes) that were recently made publically available (http://www.ncbi.nlm.nih.gov/Genbank/index.html). This type of information can be used for a number of purposes, including the development of DNA microarrays for the fathead minnow. For example, a 2000 oligonucleotide microarray has been developed, undergone initial testing, and currently is being marketed for use in field and laboratory studies with the fathead minnow (P. Larkin, EcoArray, Inc., Alachua, FL, personal communication). Other recently initiated research efforts with the fathead minnow are focused on characterization of the proteome of the species (D. Bencic, EPA, Cincinnati, OH, personal communication), as well as aspects of the metabolome (Collette et al., 2005). Given the amount of molecular research currently being conducted with the fathead minnow, there should soon be ample molecular characterization to conduct routine "omics" research with the species in conjunction with laboratory and field toxicology studies.

\section{Enhancing roles of the fathead minnow: testing and research needs}

Although the fathead minnow model has been used successfully for many years in the field of ecotoxicology, a number of steps could be taken to reduce the variability and/or increase utility of data obtained from tests with the species. The recommendations below would not only support emerging and future test applications with the fathead minnow but, in many cases, would enhance the quality/value of data derived from current test programs with the species. For example, for most standard mammalian test models (rats, mice, rabbits), a significant amount of effort has been devoted to increasing test precision by reducing within- and among-laboratory variability in results. Although the degree to which this has been achieved for mammalian models is probably not feasible for fish (at least in the near future), a number of fairly straightforward steps could be 
taken to decrease variability of data from fathead minnow tests. For example, better definition/control of genetic stocks of fathead minnows used for assays likely would enhance the quality of data derived from most test designs currently used with the species, as well as enhance interpretation of genomic data in future studies. At present there is no single definable strain/stock of fathead minnows used in the various laboratories that test this species. Although many existing fathead minnow cultures were originally obtained from the Public Health Service facility in Cincinnati $(\mathrm{OH})$, routine outbreeding of culture animals (USEPA, 1987) likely has resulted in genetic variability in stocks maintained around the world. Knowledge of the genetic composition of different stocks of fathead minnows could contribute to better understanding the basis of possible among-laboratory variations in responses to toxicants, as well as differences in responses between animals in the laboratory versus those in the field. Another measure that would help reduce within and among-laboratory variability in test data for fathead minnows (or, for that matter, any of the fish species used for toxicology work) would be standardization of diets. Next to differences in water quality characteristics (which, short of using reconstituted water, are nearly impossible to control across geographic regions), diet is probably the most variable factor in fish testing among laboratories and, perhaps, even within a given laboratory (over time). The cause of this for the fathead minnow is lack of a well-defined, formulated commercial diet that can successfully be used to support continual cultures. The most commonly used food for maintaining fathead minnows are brine shrimp, which: (1) are not well-defined nutritionally, (2) can contain uncharacterized background contaminants, and (3) vary from lot-to-lot. Although fathead minnows generally survive, grow and reproduce quite well on a brine shrimp diet, a formulated diet from a common source would be far preferable in terms of ensuring consistent within- and among laboratory animal quality. Additional factors that could be standardized, thereby potentially reducing variability of fathead minnow tests, include rearing temperature (of embryos/fry), light intensity and (culture) stocking density.

The utility of data from fathead minnow tests data could be enhanced through consideration of additional morphometric and histological endpoints. For example, while there is some information concerning early development of the fathead minnow (e.g., USEPA, 1996), this knowledge is relatively sparse compared with other vertebrate (including some fish) species. Knowing more about both embryonic and larval development (including sexual differentiation) of the fathead minnow would enable early life-stage test designs/endpoints that are more diagnostic of toxic MOA than current protocols. Another way to increase the diagnostic utility of fathead minnow tests would be through collection and evaluation of histology data. In general, histology has not been widely used in conjunction with ecotoxicology testing, due in part to a lack of standard techniques for tissue preparation and interpretive guidance for commonly used species. In the case of the fathead minnow, the recent emphasis on gonadal histopathology as a routine measurement for EDC testing has highlighted the value of this endpoint, as well as providing key methodological and interpretive techniques (e.g.,
Leino et al., 2005). There also is an increasing amount of baseline histology data for fathead minnow tissues other than gonads, which should further contribute to use of histology as a test endpoint (http://www.aquaticpath.umd.edu/fhm).

As noted above, ongoing efforts to better characterize responses of the fathead minnow to chemicals at the molecular level has the potential to greatly enhance the usefulness of data collected from both laboratory and field studies with this species. Through taking advantage of the rapidly growing and robust foundation of molecular data available for other teleosts (including cyprinids such as the zebrafish), characterization and annotation of the fathead minnow genome and proteome, particularly for genes and proteins with known relevance to specific toxicity pathways, can be achieved comparatively rapidly. Such an effort involves a relatively small investment in resources when compared with the resources and effort that would be needed to develop a comparable toxicological effects knowledge base for another small fish species. Due to the wide use of fathead minnow tests for regulatory purposes, there are significantly more chemical toxicity data for this species compared to other small fish models. For example, an analysis of the ECOTOX (ECOTOXicology) database maintained through the Duluth EPA laboratory (http://www.epa.gov/ecotox) revealed 10,943 entries for the fathead minnow, compared with 3325 for the Japanese medaka and 2009 for the zebrafish (Chris Russom, personal communication). Given the extensive knowledge-base and the robust QSAR and population models already available, among small fish, the fathead minnow arguably offers the greatest potential for linking molecular diagnostic indicators to ecologically relevant outcomes as part of predictive toxicology approaches for chemical testing in a laboratory setting. Furthermore, in North America, the fathead minnow remains the most viable small fish model for field monitoring and in situ toxicity testing in freshwater systems, so the evaluation/application of "omics" tools to field settings can be logically pursued with this species.

\section{Role of the fathead minnow in toxicology: long-term prospectus}

Thus far we have discussed the past, present, and emerging uses of the fathead minnow in the field of ecotoxicology. In this section, we conclude with some thoughts as to where testing in the field needs to go in the longer term, both generally and in the context of the fathead minnow model.

Since its first use during the mid-20th century, the fathead minnow has remained one of the paramount models in aquatic ecotoxicology due to its inherent amenability to controlled experimentation, and the continuous development and adaptation of test designs to meet evolving research and regulatory needs. Nonetheless, the same period of history has been marked by an explosive growth in chemical use in nearly all aspects of human life including agriculture, industry, commerce, and medicine, along with rapid technological and scientific advances on an unprecedented scale. With tens of thousands of chemicals currently in use, and new chemicals continually under development, it is clear that the future lies not in continued development 
of new fathead minnow test protocols to be applied to the next 10,000 chemicals (in addition to those currently in use), but in linking a strong understanding of toxicity pathways, as well as physiological function and compensation, to the extensive historical knowledge-base of ecologically relevant outcomes available for the species, in order to develop and validate a sophisticated framework of computational tools that can be used for predictive risk assessment. Although this remains a daunting challenge, many of the tools needed to make such an approach feasible are now available (e.g., substantial computing power, large-scale searchable biological databases, systems-level analytical methods). More than protocol development, the future of the fathead minnow as a model in ecotoxicology will rely on a concerted and carefully planned effort to define and describe the genome, proteome, and metabolome of the species and the responses of each to different classes of both chemical and nonchemical stressors. Such characterization should ultimately provide the data and knowledge-base needed to link together an integrated continuum of computational QSAR, pharmacokinetic, biological systems, and population models suitable for risk assessment and regulatory activities. Ultimately, testing with the fathead minnow should become a means to parameterize and validate predictive models that will help obviate the need for costly biological screening and testing with small fish.

\section{Acknowledgements}

Discussions with a number of scientists, including Donald Mount, Charles Stephan, Christine Russom, Leslie Touart, Jerry Smrchek, and David Miller helped in writing this paper. Christine Russom, Jim Lazorchak and Tom Hutchinson provided valuable comments on an earlier draft of the manuscript. This paper has been reviewed in accordance with official EPA policy. Mention of tradenames does not indicate endorsement by the Federal government.

\section{References}

ASTM, 2000a. Standard guide for conducting acute toxicity tests with fishes, macroinvertebrates, and amphibians. Method E-729-96. In: Annual Book of ASTM Standards, vol. 11.05. West Conshohocken, PA, USA, pp. 941-967.

ASTM, 2000b. Standard guide for conducting early life-stage toxicity tests with fishes. Method E 1241-98. In: Annual Book of ASTM Standards, vol. 11.05. West Conshohocken, PA, USA, pp. 941-967.

American Public Health Association, American Water Works Association, and Water Pollution Control Federation, 1960. Standard Methods for the Examination of Water and Wastewater, 11th ed. American Public Health Association, New York, NY, USA.

Andrews, A.K., Flickinger, S.A., 1973. Spawning requirements and characteristics of the fathead minnow. Proc. Annu. Conf. Southeast. Assoc. Game Fish Comm. 27, 759-766.

Ankley, G.T., Johnson, R.D., 2004. Small fish models for identifying and assessing the effects of endocrine-disrupting chemicals. Inst. Lab. Anim. Res. (ILAR) J. 45, 469-483.

Ankley, G.T., Kuehl, D.W., Kahl, M.D., Jensen, K.M., Linnum, A., Leino, R.L., Villeneuve, D.A., 2005. Reproductive and developmental toxicity and bioconcentration of perfluorooctanesulfonate (PFOS) in a partial-life cycle test with the fathead minnow (Pimephales promelas). Environ. Toxicol. Chem. 24, 2316-2324.
Ankley, G.T., DeFoe, D.L., Kahl, M.D., Jensen, K.M., Makynen, E.A., Miracle, A., Hartig, P., Gray, L.E., Cardon, M., Wilson, V., 2004. Evaluation of the model anti-androgen flutamide in the fathead minnow (Pimephales promelas). Environ. Sci. Technol. 38, 6327-6822.

Ankley, G.T., Jensen, K.M., Makynen, E.A., Kahl, M.D., Korte, J.J., Hornung, M.W., Henry, T.R., Denny, J.S., Leino, R.L., Wilson, V.S., Cardon, M.D., Hartig, P.C., Gray, L.E., 2003. Effects of the androgenic growth promoter $17 \beta$-trenbolone on fecundity and reproductive endocrinology of the fathead minnow. Environ. Toxicol. Chem. 22, 1350-1360.

Ankley, G.T., Jensen, K.M., Kahl, M.D., Korte, J.J., Makynen, E.A., 2001. Description and evaluation of a short-term reproduction test with the fathead minnow (Pimephales promelas). Environ. Toxicol. Chem. 20, 1276-1290.

Bardach, J.E., Bernstein, J.J., Hart, J.S., Brett, J.R., 1966. Tolerance to temperature extremes: animals. Part IV. Fishes. In: Altman, P.L., Dittmer, D. (Eds.), Environmental Biology. Federation of American Societies for Experimental Biology, Bethesda, MD, USA, pp. 37-80.

Benoit, D.A., Carlson, R.W., 1977. Spawning success of fathead minnows on selected artificial substrates. Prog. Fish-Cult. 39, 67-69.

Besser, J.M., Wang, N., Dwyer, F.J., Mayer Jr., F.L., Ingersoll, C.G., 2005. Assessing contaminant sensitivity of endangered and threatened aquatic species. Part II. Chronic toxicity of copper and pentachlorophenol to two endangered species and two surrogate species. Arch. Environ. Contam. Toxicol. 48, 155-165.

Beverton, R.J.H., Holt, S.J., 1957. On the dynamics of exploited fish populations (Great Britain). Ministry of Agriculture, Fisheries and Food Fishery Investigations (Series 2) 19, 5-533.

Bradbury, S.P., Feijtel, T.C.J., Van Leeuwen, C.J., 2004. Meeting the scientific needs of ecological risk assessment in a regulatory context. Environ. Sci. Technol. 38, 463A-470A.

Bradbury, S.P., Russom, C.L., Ankley, G.T., Schultz, T.W., Walker, J.D., 2003. Overview of data and conceptual approaches for derivation of quantitative structure-activity relationships for ecotoxicological effects of organic chemicals. Environ. Toxicol. Chem. 22, 1789-1798.

Brian, J.V., Harris, C.A., Scholze, M., Backhaus, T., Booy, P., Lamoree, M., Pojana, G., Jonkers, N., Runnalls, T., Bonfa, A., Marcomini, A., Sumpter, J.P., 2005. Accurate prediction of the response of freshwater fish to a mixture of estrogenic chemicals. Environ. Health Perspect. 113, 721-728.

Broderius, S., Kahl, M., 1985. Acute toxicity of organic chemical mixtures to the fathead minnow. Aquat. Toxicol. 6, 307-322.

Broderius, S.J., Kahl, M.D., Elonen, G.E., Hammermeister, D.E., Hoglund, M.D., 2005. A comparison of the lethal and sublethal toxicity of organic chemical mixtures to the fathead minnow (Pimephales promelas). Environ. Toxicol. Chem. 24, 3117-3127.

Broderius, S.J., Kahl, M.D., Hoglund, M.D., 1995. Use of joint toxic response to define the primary mode of toxic action for diverse industrial organic chemicals. Environ. Toxicol. Chem. 14, 1591-1605.

Brown, A.R., Riddle, A.M., Cunningham, N.L., Kedwars, T.J., Shillabeer, N.S., Hutchinson, T.H., 2003. Predicting the effects of endocrine disrupting chemicals on fish populations. Hum. Ecol. Risk Assess. 9, 761788.

Brungs, W.A., 1971a. Chronic effects of elevated temperature on the fathead minnow (Pimephales promelas Rafinesque). Trans. Am. Fish. Soc. 100, 659-664.

Brungs, W.A., 1971b. Chronic effects of low dissolved oxygen concentrations on the fathead minnow (Pimephales promelas). J. Fish. Res. Board Can. 28, 1119-1123.

Call, D.J., Geiger, D.L. (Eds.), 1992. Subchronic Toxicities of Industrial and Agricultural Chemicals to Fathead Minnows (Pimephales promelas). Center for Lake Superior Environmental Studies, vol. 1. University of Wisconsin-Superior, Superior, WI, USA.

Cole, K.S., Smith, R.J., 1987. Male courting behavior in the fathead minnow Pimephales promelas. Environ. Biol. Fish. 18, 235-239.

Collette, T., Eckman, D., Kenneke, J., Whitehead, T., Villeneuve, D., Kahl, M., Jensen, K., Ankley, G., 2005. Metabolomics as a diagnostic tool for small fish toxicology research. In: Abstracts, Annual Meeting, Society of Environmental Toxicology and Chemistry, Baltimore, MD, USA. 
Cook, P.M., Erickson, R.J., Spehar, R.L., Bradbury, S.P., Ankley, G.T., 1993. Interim report on data and methods for assessment of 2,3,7,8tetrachlorodibenzo- $p$-dioxin risks to aquatic and associated wildlife. EPA600/R-93/055. USEPA, Duluth, MN.

Desbrow, C., Routledge, E.J., Brighty, G.C., Sumpter, J.P., Waldock, M., 1998. Identification of estrogenic chemicals in STW effluent 2. Chemical fractionation and in vitro biological screening. Environ. Sci. Technol. 32, $1549-1558$.

Devine, G., 1968. A study of the smallmouth bass in ponds with special consideration of minnows and decapods as forage. Thesis, University of Missouri, Columbia, MO, USA.

Doherty, F.G., 1983. Interspecies correlations of acute aquatic median lethal concentration for four standard testing species. Environ. Sci. Technol. 17, 661-666.

Doudoroff, P., Katz, M., 1953. Critical review of literature on the toxicity of industrial wastes and their components to fish II. The metals, as salts. Sewage Ind. Wastes 25, 802-839.

Doudoroff, P., Katz, M., 1950. Critical review of literature on the toxicity of industrial wastes and their components to fish. I. Alkalies, acids, and inorganic gasses. Sewage Ind. Wastes 22, 1432-1458.

Dwyer, F.J., Mayer, F.L., Sappington, L.C., Buckler, D.R., Bridges, C.M., Greer, I.E., Hardesty, D.K., Henke, C.E., Ingersoll, C.G., Kunz, J.L., Whites, D.W., Augspurger, T., Mount, D.R., Hattala, K., Neuderfer, G.N., 2005a. Assessing contaminant sensitivity of endangered and threatened aquatic species. Part 1. Acute toxicity of five chemicals. Arch. Environ. Contam. Toxicol. 48, 143-154.

Dwyer, F.J., Haresty, D.K., Henke, C.E., Ingersoll, C.G., Whites, D.W., Augspurer, T., Canfield, T.J., Mount, D.R., Mayer, F.L., 2005b. Assessing contaminant sensitivity of endangered and threatened aquatic species. Part III. Effluent toxicity tests. Arch. Environ. Contam. Toxicol. 48, 174183.

Eddy, S., Underhill, J.C., 1974. Northern Fishes. University of Minnesota Press, Minneapolis, MN, USA.

Erickson, R.J., 1985. An evaluation of mathematical models for the effects of $\mathrm{pH}$ and temperature on ammonia toxicity to aquatic organisms. Water Res. 19, 1047-1058.

Erickson, R.J., Benoit, D.A., Mattson, V.R., Nelson Jr., H.P., Leonard, E.N., 1996. The effects of water chemistry on the toxicity of copper to fathead minnows. Environ. Toxicol. Chem. 15, 181-193.

Flickinger, S.A., 1969. Determination of sexes in the fathead minnow. Trans. Am. Fish. Soc. 98, 526-527.

Gale, W.F., Bunyak, G.L., 1982. Fecundity and spawning frequency of the fathead minnow-a fractional spawner. Trans. Am. Fish. Soc. 111, 35-40.

Gleason, T.R., Nacci, D.E., 2001. Risks of endocrine-disrupting compounds to wildlife: Extrapolating from effects on individuals to population response. Hum. Ecol. Risk Assess. 7, 1027-1042.

Gobas, F.A.P.C., Morrison, H.A., 2000. Bioconcentration and biomagnification in the aquatic environment. In: Boethling, R.S., Mackay, D. (Eds.), Handbook of Property Estimation Methods for Chemicals: Environmental and Health Sciences. CRC Press LLC, Boca Raton, FL, USA, pp. 189-232.

Grist, E.P.M., Wells, N.C., Whitehouse, P., Brighty, G., Crane, M., 2003. Estimating the effects of $17 \alpha$-ethinylestradiol on populations of the fathead minnow Pimephales promelas: are conventional toxicological endpoints adequate? Environ. Sci. Technol. 37, 1609-1616.

Halm, S., Kwon, J.Y., Rand-Weaver, M., Sumpter, J.P., Pounds, N., Hutchinson, T.H., Tyler, C.R., 2003. Cloning and gene expression of P450 17 $\alpha-$ hydroxylase, 17,20-lyase cDNA in the gonads and brain of the fathead minnow Pimephales promelas. Gen. Comp. Endocrinol. 130, 256-266.

Halm, S., Rand-Weaver, M., Sumpter, J.P., Tyler, C.R., 2001. Cloning and molecular characterization of an ovarian-derived (brain-like) P450 aromatase cDNA and development of a competitive RT-PCR assay to quantify its expression in the fathead minnow (Pimephales promelas). Fish Physiol. Biochem. 24, 49-62.

Harries, J.E., Runnalls, T., Hill, E., Harris, C., Maddix, S., Sumpter, J.P., Tyler, C.R., 2000. Development of a reproductive performance test for endocrine disrupting chemicals using pair-breeding fathead minnows (Pimephales promelas). Environ. Sci. Technol. 34, 3003-3011.
Hasler, A.D., Thomsen, H.P., Neess, J.C., 1946. Facts and comments on raising two common bait minnows. Wisconsin Conservation Bulletin No. 310-A-46.

Held, J.W., Peterka, J.J., 1974. Age, growth, and food habits of the fathead minnow, Pimephales promelas, in North Dakota saline lakes. Trans. Am. Fish. Soc. 103, 743-756.

Hemming, J.M., Allen, H.J., Thuesen, K.A., Turner, P.K., Waller, W.T., Lazorchak, J.M., Lattier, D., Chow, M., Denslow, N., Venables, B., 2004. Temporal and spatial variability in the estrogenicity of a municipal wastewater effluent. Ecotoxicol. Environ. Saf. 57, 303-310.

Hemming, J.M., Waller, W.T., Chow, M.C., Denslow, N.D., Venables, B., 2001. Assessment of the estrogenicity and toxicity of a domestic wastewater effluent flowing through a constructed wetland system using biomarkers in male fathead minnows (Pimephales promelas Rafinesque, 1820). Environ. Toxicol. Chem. 20, 2268-2275.

Hunn, J.B., 1989. History of acute toxicity tests with fish, 1863-1987. In: Invest. Fish Control 98, US Fish and Wildlife Service, LaCrosse, WI, USA.

Hutchinson, T.H., Ankley, G.T., Segner, H., Tyler, C.R., 2006. Screening and testing for endocrine disruption in fish-biomarkers as signposts not traffic lights in risk assessment. Environ. Health Perspect, in press.

Isaak, D., 1961. The ecological life history of the fathead minnow, Pimephales promelas (Rafinesque). PhD Thesis, University of Minnesota. St. Paul, MN.

Jensen, K.M., Korte, J.J., Kahl, M.D., Pasha, M.S., Ankley, G.T., 2001 Aspects of basic reproductive biology and endocrinology in the fathead minnow (Pimephales promelas). Comp. Biochem. Physiol. 128C, $127-141$.

Korte, J.J., Kahl, M.D., Jensen, K.M., Pasha, M.S., Parks, L.G., LeBlanc, G.A., Ankley, G.T., 2000. Fathead minnow vitellogen: complementary DNA sequence and messenger RNA and protein expression after $17 \beta$ estradiol treatment. Environ. Toxicol. Chem. 19, 972-981.

Länge, R., Hutchinson, T.H., Croudace, C.P., Siegmund, F., Schweinfurth, H., Hampe, P., Panter, G.H., Sumpter, J.P., 2001. Effects of the synthetic estrogen $17 \alpha$-ethinylestradiol on the life-cycle of the fathead minnow (Pimephales promelas). Environ. Toxicol. Chem. 20, 1216-1227.

Lattier, D.L., Reddy, T.V., Gordon, D.A., Lazorchak, J.M., Smith, M.E., Williams, D.E., Wiechman, B., Flick, R.W., Miracle, A.L., Toth, G.P., 2002. 17 $\alpha$-Ethynylestradiol-induced vitellogenin gene transcription quantified in livers of adult males, larvae, and gills of fathead minnows (Pimephales promelas). Environ. Toxicol. Chem. 21, 2385-2393.

Leino, R.L., Jensen, K.M., Ankley, G.T., 2005. Gonadal histology and characteristic histopathology associated with endocrine disruption in the adult fathead minnow (Pimephales promelas). Environ. Toxicol. Pharmacol. 19, 85-98.

Manner, H.W., Casimira, C.M., 1974. Early embryology of the fathead minnow Pimephales promelas Rafinesque. Anat. Rec. 180, 99-109.

May, R.M., 1974. Biological populations with nonoverlapping generations: stable points, stable cycles, and chaos. Science 186, 645-647.

McCarraher, D.B., Thomas, R., 1968. Some ecological observations on the fathead minnow Pimephales promelas in the alkaline waters of Nebraska. Trans. Am. Fish. Soc. 97, 52-55.

McKim, J.M., 1977. Evaluation of tests with early life stages of fish for predicting long-term toxicity. J. Fish. Res. Board Can. 34, 1148-1154.

McMillan, V.E., Smith, R.J., 1974. Agonistic and reproductive behaviour of the fathead minnow (Pimephales promelas Rafinesque). Z. Tierpsychol. $34,25-58$

Miller, D.H., Ankley, G.T., 2004. Modeling impacts on populations: fathead minnow (Pimephales promelas) exposure to the endocrine disruptor $17 \beta$ trenbolone as a case study. Ecotoxicol. Environ. Saf. 59, 1-9.

Ming, F.W., Noakes, D.L.G., 1984. Spawning site selection and competition in minnows (Pimephales notatus and P. promelas) (Pisces, Cyprinidae). Biol. Behav. 9, 227-234.

Miracle, A.L., Ankley, G.T., 2005. Ecotoxicogenomics: linkages between exposure and effects in assessing risks of aquatic contaminants to fish Reprod. Toxicol. 19, 321-326.

Miracle, A.L., Toth, G., Lattier, D.L., 2003. The path from molecular indicators of exposure to describing dynamic biological systems in an 
aquatic organism: microarrays and the fathead minnow. Ecotoxicology $12,457-462$.

Mount, D.I., 1977. Present approaches to toxicity testing-a perspective. In: Mayer, F.L., Hamelink, J.L. (Eds.), Aquatic Toxicology and Hazard Evaluation. ASTM STP 634. American Society for Testing and Materials, Philadelphia, PA, USA, pp. 5-14.

Mount, D.I., 1973. Chronic effect of low $\mathrm{pH}$ on fathead minnow survival, growth and reproduction. Water Res. 7, 987-993.

Mount, D.I., Stephan, C.E., 1967. A method for establishing acceptable toxicant limits for fish-malathion and the butoxyethanol ester of 2,4-D. Trans. Am. Fish. Soc. 96, 185-193.

Norberg, T.J., Mount, D.I., 1985. A new fathead minnow (Pimephales promelas) subchronic toxicity test. Environ. Toxicol. Chem. 4, 711-718.

OECD, 1992a. Fish acute toxicity test. Guideline 203. In: OECD Guidelines for Testing of Chemicals, Section 2. OECD, Paris, France.

OECD, 1992b. Fish early life-stage toxicity test. Guideline 204. In: OECD Guidelines for Testing of Chemicals, Section 2. OECD, Paris, France.

Palace, V., Kidd, K., Blanchfield, P., Evans, B., Baron, C., Wautier, K., 2002a. Reproductive effects in fish from a lake experimentally treated with the synthetic estrogen ethynylestradiol. In: Abstracts, 23rd Annual Meeting, 16-20 November. Society of Environmental Toxicology and Chemistry, Salt Lake City, UT, USA.

Palace, V.P., Evans, E., Wautier, K., Baron, C., Vandenbyllardt, L., Vendersteen, W., Kidd, K., 2002b. Induction of vitellogenin and histological effects in wild fathead minnows from a lake experimentally treated with the synthetic estrogen ethynylestradiol. Water Qual. Res. J. Can. 37, 637-650.

Panter, G.H., Hutchinson, T.H., Länge, R., Wale, G., Sumpter, J.P., van Aerle, R., Tyler, C.R., 2002. Quantifying histological development in the gonads of sexually maturing fathead minnows (Pimephales promelas): phase two. CEFIC-EMSG AQ005. In: CEFIC-EMSG Aquatic Research Programme Progress Report Project A, Astra-Zeneca, Brixham, UK.

Panter, G.H., Thompson, R.S., Sumpter, J.P., 1998. Adverse reproductive effects in male fathead minnows (Pimephales promelas) exposed to environmentally relevant concentrations of the natural oestrogens, oestradiol and oestrone. Aquat. Toxicol. 42, 243-253.

Paquin, P.R., Gorsuch, J.W., et al., 2002. The biotic ligand model: a historical overview. Comp. Biochem. Physiol. 133C, 3-35.

Parrott, J.L., 2005. Overview of methodology and endpoints in fathead minnow lifecycle tests assessing pulp and paper mill effluents. Water Qual. Res. J. Can. 40, 334-346.

Penny, C., Adams, C., 1863. Fourth Report, Royal Commission on Pollution on Rivers in Scotland, vol. 2. Evidence. London, UK (in Jones 1964), pp. 377-391.

Pickering, Q.H., 1988. Evaluation and comparison of two short-term fathead minnow tests for estimating chronic toxicity. Water Res. 22, 883-893.

Pickering, Q.H., Lazorchak, J.M., 1995. Evaluation of robustness of the fathead minnow, Pimephales promelas, larval survival and growth test, U.S. EPA method 1000.0. Environ. Toxicol. Chem. 14, 653-659.

Radcliff, L., 1931. Propagation of minnows. Trans. Am. Fish. Soc. 61, 131-137.

Ricker, W.E., 1975. Computation and interpretation of biological statistics of fish populations. Fish Research Board of Canada, Ottawa Canada Bulletin 191.

Russom, C.L., Bradbury, S.P., Broderius, S.J., Drummond, R.A., Hammermeister, D.E., 1997. Predicting modes of toxic action from chemical structure: acute toxicity in the fathead minnow (Pimephales promelas). Environ. Toxicol. Chem. 16, 948-967.

Sappington, L.C., Mayer, F.L., Dwyer, F.J., Buckler, D.R., Jones, J.R., Ellersieck, M.R., 2001. Contaminant sensitivity of threatened and endangered fishes compared to standard surrogate species. Environ. Toxicol. Chem. 20, 2869-2876.

Shrader, E.A., Henry, T.R., Greeley, M.S., Bradley, B.P., 2003. Proteomics in the zebrafish exposed to endocrine disrupting chemicals. Ecotoxicology 12, 485-488.

Smith, R.J.F., 1974. Effects of $17 \alpha$-methyltestosterone on the dorsal pad and tubercles of fathead minnows (Pimephales promelas). Can. J. Zool. 52 1031-1038
Smith, R.J.F., Murphy, B.D., 1974. Functional morphology of the dorsal pad in fathead minnows (Pimephales promelas). Trans. Am. Fish. Soc. 103, $65-72$.

Smrchek, J., Clements, R., Morcock, R., Rabert, W., 1993. Assessing ecological hazard under TSCA: methods and evaluation of data. In: Landis, W.G., Hughes, J.S., Lewis, M.A. (Eds.), Environmental Toxicology and Risk Assessment. ASTM STP 1179. American Society for Testing and Materials, Philadelphia, PA, USA, pp. 22-39.

Snape, J.R., Maund, S.J., Pickford, D.B., Hutchinson, T.H., 2004. Ecotoxicogenomics: the challenge of integrating genomics into aquatic and terrestrial ecotoxicology. Aquat. Toxicol. 67, 143-154.

Stephan, C.E., 1989. Topics on expressing and predicting results of life-cycle tests. In: Suter II, G.W., Lewis, M.A. (Eds.), Aquatic Toxicology and Environmental Fate, vol. 11. American Society for Testing and Materials, Philadelphia, PA, USA, pp. 263-272, ASTM STP 1007.

Stephan, C.E., Mount, D.I., Hansen, D.J., Gentile, J.H., Chapman, G.A., Brungs, W.E., 1985. Guidelines for Deriving Numerical National Water Quality Criteria for the Protection of Aquatic Organisms and Their Uses. NTIS, Springfield, VA, PB85-227049.

Suter II, G.W., Rosen, A.E., 1988. Comparative toxicology for risk assessment of marine fishes and crustaceans. Environ. Sci. Technol. 22, 548-555.

Ternes, T.A., Stumpf, M., Mueller, J., Haberer, K., Nilken, R.D., Servos, M., 1999. Behavior and occurrence of estrogens in municipal sewage treatment plants. I. Investigations in Germany, Canada and Brazil. Sci. Total Environ. 225, 81-90.

Thurston, R.V., Gilfoil, T.A., Meyn, E.L., Zajdel, R.K., Aoki, T.I., Veith, G.D., 1985. Comparative toxicity of 10 organic chemicals to 10 common aquatic species. Water Res. 19, 1145-1155.

USEPA, 2002. A short-term method for assessing the reproductive and developmental toxicity of endocrine-disrupting chemicals using the fathead minnow (Pimephales promelas). EPA-600/R-01/067. USEPA, Cincinnati, $\mathrm{OH}$

USEPA, 1999. Update of Ambient Water Quality Criteria for Ammonia. Office of Water, Washington, DC

USEPA, 1998. Endocrine Disruptor Screening and Testing Advisory Committee (EDSTAC) Report. Office of Prevention, Pesticides and Toxic Substances, Washington, DC.

USEPA, 1996. Prehatching development of the fathead minnow Pimephales promelas Rafinesque. EPA/600/R-96/079. USEPA, Washington, DC.

USEPA, 1994. Short-term methods for estimating the chronic toxicity of effluents and receiving water to freshwater organisms, 3rd ed. EPA/600/491/002. USEPA, Cincinnati, OH.

USEPA, 1991. Technical support document for water quality-based toxics control. EPA/505/2-90/001. USEPA, Washington, DC.

USEPA, 1989. Pesticide assessment guidelines. Subdivision E, hazard evaluation: wildlife and aquatic organisms. EPA/540/09-82/024. USEPA, Washington, DC.

USEPA, 1987. Guidelines for the culture of fathead minnows Pimephales promelas for use in toxicity tests. EPA/600/3-87/001. USEPA, Duluth, $\mathrm{MN}$.

USEPA, 1982. User's guide for conducting life-cycle chronic toxicity tests with fathead minnows. EPA/600/8-81/001. USEPA, Duluth, MN.

Van Aerle, R., Pounds, N., Hutchinson, T.H., Maddix, S., Tyler, C.R., 2002. Window of sensitivity for the estrogenic effects of ethinylestradiol in early life-stages of fathead minnow, Pimephales promelas. Ecotoxicology 11, $423-434$

Veith, G.D., Kosian, P., 1983. Estimating bioconcentration potential from octanol/water partition coefficients. In: Mackay, D., Paterson, S., Eisenreich, S.J., Simmons, M.S. (Eds.), Physical Behavior of PCBs in the Great Lakes. Ann Arbor Science, Ann Arbor, MI, USA, pp. 269-282.

Veith, G.D., Greenwood, B.E., Hunter, R.S., Niemi, G.J., Regal, R.R., 1988. On the intrinsic dimensionality of chemical structure space. Chemosphere 17, 1617-1630.

Veith, G.D., DeFoe, D.L., Bergstedt, B.V., 1979. Measuring and estimating the bioconcentration factor of chemicals in fish. J. Fish. Res. Board Can. 36, 1040-1048.

Viant, M.R., Rosenblum, E.S., Tjeerdema, R.S., 2003. NMR-based metabolomics: a powerful approach for characterizing the effects of 
environmental stressors on organism health. Environ. Sci. Technol. 37, 4982-4989.

Villeneuve, D., Miracle, A., Degitz, S., Korte, J., Kahl, M., Jensen, K., Ankley, G., 2005. Quantitative RT-PCR assays for fathead minnow gonadotropin (FSH $\beta$ and $\mathrm{LH} \beta$ subunits) mRNA expression. In: Abstracts, Annual Meeting, Society of Environmental Toxicology and Chemistry, Baltimore, MD, USA.

Wabuke-Bunoti, M.A.N., Firling, C.E., 1983. The prehatching development of the thyroid gland of the fathead minnow, Pimephales promelas (Rafinesque). Gen. Comp. Endocrinol. 49, 320-331.
Wilson, V.S., Cardon, M.C., Thornton, J., Korte, J.J., Ankley, G.T., Welch, J., Gray Jr., L.E., Hartig, P.C., 2004. Cloning and in vitro expression and characterization of the androgen receptor and isolation of estrogen receptor $\alpha$ from the fathead minnow (Pimephales promelas). Environ. Sci. Technol. 38, 6314-6321.

Zeeman, M.G., 1995. Ecotoxicity testing and estimation methods developed under section 5 of the Toxic Substances Control Act (TSCA). In: Rand, G. (Ed.), Fundamentals of Aquatic Toxicology: Effects, Environmental Fate, and Risk Assessment. Taylor and Francis, Washington, DC, USA, pp. 703-715. 